\title{
Rancang Bangun Aplikasi Sistem Pakar Berbasis Android Menggunakan Metode Forward Chaining Untuk Mendiagnosis Kerusakan Pada Hardware Laptop
}

\author{
Budi Wijaya \\ Program Studi Teknik Informatika \\ Universitas Ciputra \\ arrowbudi9914@gmail.com
}

\author{
Rinabi Tanamal \\ Program Studi Teknik Informatika \\ Universitas Ciputra \\ r.tanamal@ciputra.ac.id
}

\begin{abstract}
Abstrak - Kebutuhan dan penggunaan laptop yang banyak sering diikuti oleh banyaknya permasalahan yang sering terjadi pada laptop yang digunakan. Beberapa permasalahan yang sering terjadi, seperti layar laptop tampil blue screen, baterai laptop yang cepat habis, keyboard tidak berfungsi dengan normal, ataupun laptop yang tiba-tiba mati dengan sendirinya. Bila permasalahan tersebut timbul, biasanya pengguna laptop yang masih awam tidak mengerti apa yang harus mereka lakukan. Biaya perbaikan laptop yang harus dibayar termasuk mahal. Tidak hanya itu, jika permasalahan tersebut dibawa ke tempat servis laptop, ada beberapa teknisi laptop yang salah mendiagnosis kerusakannya karena kurang pemahaman atau pengalaman mengenai masalahnya. Maka dari itu, untuk mengatasi beberapa permasalahan yang sering terjadi di atas, dibuatlah aplikasi sistem pakar berbasis Android menggunakan metode forward chaining yang dapat mendiagnosis kerusakan hardware laptop secara tepat. Expert system shell yang digunakan adalah McGoo yang selanjutnya menggunakan Thunkable sebagai pembuat aplikasi sistem pakar. Dengan sistem ini, diharapkan user dapat lebih cepat, mudah, dan efisien dalam memperbaiki laptop dan mengambil keputusan secara tepat. Kesimpulan yang didapat menunjukkan bahwa pembentukan pohon keputusan untuk diagnosis kerusakan hardware laptop dapat diimplementasikan ke dalam aplikasi. Berdasarkan hasil pengujian, aplikasi sistem pakar yang telah terbentuk dapat diakses melalui smartphone berbasis Android sehingga dapat membantu pengguna laptop untuk memahami dan mengatasi masalah dan gangguan pada bagian hardware laptop.

Kata Kunci: Android, Forward Chaining, Kerusakan Laptop, McGoo, Sistem Pakar.
\end{abstract}

\section{PENDAHULUAN}

A. Latar Belakang

Seiring dengan perubahan zaman, perkembangan teknologi informasi memberikan pengaruh yang cukup besar pada kehidupan umat manusia. Teknologi tersebut dikembangkan untuk mempermudah serta mempercepat berbagai macam kegiatan yang biasanya dilakukan oleh manusia. Laptop merupakan salah satu perkembangan teknologi informasi yang berasal dari perubahan konsep komputer dekstop. Berdasarkan data yang diolah oleh IDC Indonesia, laptop notebook mendominasi pasar komputer desktop di Indonesia pada tahun 2017. Market share laptop notebook berkisar antara 70-75\% tiap kuartal [1]. Dengan data tersebut, dapat disimpulkan bahwa laptop banyak diminati karena memiliki mobilitas yang tinggi dan harganya yang cukup terjangkau di berbagai kalangan masyarakat. Kebutuhan dan penggunaan laptop yang banyak tersebut sering juga diikuti oleh banyaknya permasalahan yang sering terjadi pada laptop yang digunakan. Beberapa permasalahan yang sering terjadi, seperti layar laptop tampil blue screen, baterai laptop yang cepat habis, keyboard tidak berfungsi dengan normal, ataupun laptop yang tiba-tiba mati dengan sendirinya. Bila permasalahan tersebut timbul, biasanya pengguna laptop yang masih awam tidak mengerti apa yang harus mereka lakukan. Biaya perbaikan laptop yang harus dibayar termasuk mahal. Tidak hanya itu, jika permasalahan tersebut dibawa ke tempat servis laptop, ada beberapa teknisi laptop yang salah mendiagnosis kerusakannya karena kurang pemahaman atau pengalaman mengenai masalahnya. Maka dari itu, untuk mengatasi beberapa permasalahan yang sering terjadi di atas, dibuatlah aplikasi sistem pakar berbasis Android yang dapat mendiagnosis kerusakan laptop secara tepat. Dengan sistem ini, diharapkan user dapat lebih cepat, mudah, dan efisien dalam memperbaiki laptop dan mengambil keputusan secara tepat.

\section{B. Rumusan Masalah}

Berdasarkan latar belakang yang disampaikan di atas, maka rumusan masalah yang akan dibahas pada penelitian ini adalah "Bagaimana merancang bangun aplikasi sistem pakar berbasis Android menggunakan metode forward chaining untuk mendiagnosis kerusakan pada hardware laptop yang digunakan untuk membantu mengambil keputusan bagi pengguna maupun teknisi laptop?" 


\section{Tujuan Penulisan}

Tujuan dari penelitian "Rancang Bangun Aplikasi Sistem Pakar Berbasis Android Menggunakan Metode Forward Chaining untuk Mendiagnosis Kerusakan pada Hardware Laptop" adalah untuk menghasilkan sebuah aplikasi sistem pakar berbasis Android yang dapat membantu pengguna awam maupun teknisi laptop mengambil keputusan pada kerusakan hardware laptop tersebut.

\section{Ruang Lingkup}

Untuk mengarahkan penyusunan dan penelitian ini, peneliti membatasi ruang lingkup penelitian sebagai berikut:

1. Laptop yang diteliti merupakan laptop tahun produksi 2010-2018, yang menggunakan sistem operasi versi Windows 7-Windows 10.

2. Laptop yang diteliti tidak termasuk laptop produk dari brand Apple.

3. Sistem pakar yang dirancang khusus untuk mendiagnosis ataupun mendeteksi kerusakan pada bagian hardware laptop saja.

4. Penyusunan fakta, aturan, dan ilmu pengetahuan berasal dari observasi dan hasil wawancara terhadap teknisi yang menangani laptop sebagai pakar. Observasi sendiri dilakukan dengan cara melihat secara detail proses atau kegiatan yang dipraktikkan oleh teknisi untuk melakukan diagnosis. Hasil wawancara didapatkan melalui tanya jawab mengenai proses diagnosis kerusakan laptop oleh teknisi.

5. Pembentukan fakta dan aturan sistem pakar dibuat dengan software expert system shell McGoo yang selanjutnya diimplementasikan ke dalam aplikasi Android.

6. Metode penalaran yang dipakai untuk penelitian ini menggunakan metode forward chaining.

\section{LANDASAN TEORI}

\section{A. Sistem Pakar}

Sistem Pakar atau yang dikenal dengan istilah Expert System merupakan sistem komputer yang fungsinya mengikuti semua aspek kemampuan pengambilan keputusan yang dimiliki oleh seorang pakar. Dengan kata lain, sistem ini berjalan layaknya seorang pakar khusus yang mampu memecahkan masalah rumit [2].

\section{B. Metode Forward Chaining}

Metode Runut Maju atau istilahnya Forward Chaining adalah metode dimana pencocokan pernyataan atau faktanya dimulai dari fakta atau $I F$ terlebih dahulu, lalu dilanjutkan dengan THEN yang berisi dengan hipotesisnya [2].

\section{McGoo}

Program ini merupakan sebuah aplikasi untuk membuat sistem pakar berbasis web secara online [3].

\section{Android}

Android merupakan sistem operasi dengan Linux sebagai basisnya dan dapat digunakan untuk ponsel. Android menyediakan platform yang terbuka bagi para developer atau istilahnya open source, sehingga memungkinkan banyaknya aplikasi yang tercipta sendiri, kemudian dapat dijalankan pada smartphone [4].

\section{E. Pohon Keputusan}

Pohon Keputusan atau yang sering dikenal dengan istilah Decision Tree adalah suatu teknik dalam analisis pemecahan masalah dengan cara pemetaan mengenai alternatif-alternatif keputusan yang berbentuk seperti pohon. Pemetaan tersebut juga menunjukkan berbagai faktor probabilitas yang mempengaruhinya hingga pada akhirnya terdapat estimasi kesimpulan bila memilih salah satu alternatif yang tersedia. Metode decision tree ini mengubah fakta yang sangat besar menjadi pohon keputusan yang berisi aturan dan berguna dalam pengambilan keputusan [5].

\section{ANALISIS DAN DESAIN}

\section{A. Pakar}

Dalam penelitian ini, peneliti mengumpulkan informasi dan pengetahuan dari 5 teknisi laptop yang disebut sebagai pakar. Semua pakar yang dipilih oleh peneliti merupakan teknisi yang telah berpengalaman dalam bidang jasa service laptop lebih dari 3 tahun dan juga ada yang sejak tahun 2000 sampai sekarang sudah memahami bidang ini. Mereka telah menekuninya dan mengatasi berbagai jenis kerusakan laptop terutama bagian hardware laptop. Para teknisi laptop tersebut bekerja di berbagai toko yang berbeda dalam HiTech Mall Surabaya, dimana tempat ini menjadi pusat perdagangan laptop dan komputer terbesar di Indonesia Timur. Hal tersebut dapat membuktikan bahwa pemilihan kelima pakar ini sangat tepat karena mereka telah mendalami berbagai macam masalah kerusakan hardware laptop.

\section{B. Observasi}

Dalam tahap ini, peneliti melakukan pengamatan terhadap pakar dalam proses kerja pakar tersebut untuk menangani laptop. Kegiatan observasi ini dilakukan langsung di tempat kerja teknisi laptop, tepatnya di Hi-Tech Mall Surabaya. Observasi dilakukan dengan mengamati dan memahami bagaimana cara pakar dalam menangani dan mengatasi kerusakan hardware laptop dari para customer dari gejala awal penyebab kerusakan sampai dengan mencari solusi yang tepat untuk memperbaiki laptopnya. Tujuan dari tahap observasi, yaitu peneliti dapat mengetahui bagaimana langkah-langkah yang tepat untuk mendiagnosis kerusakan hardware laptop dari awal hingga kembali berfungsi dengan normal. Hasil dari observasi ini selanjutnya akan membantu peneliti menyusun berbagai pertanyaan lebih lanjut guna mendapatkan pengetahuan yang lebih lengkap, dimana hal tersebut dibutuhkan untuk perancangan aturan-aturan (rule) dan pohon keputusan (decision tree). 


\section{Wawancara}

Tahap ini merupakan tahap untuk mengumpulkan informasi dan pengetahuan tambahan dari beberapa teknisi, yang disebut dengan pakar. Cara pengumpulannya, yaitu dengan wawancara langsung untuk mendapatkan informasi lebih lengkap mengenai gejala-gejala apa yang menyebabkan kerusakan hingga kesimpulan bagian hardware laptop mana yang rusak dan cara mengatasinya. Wawancara juga digunakan untuk melengkapi pengetahuan yang ada bila ada kekurangan informasi dalam kegiatan observasi sebelumnya. Semua informasi yang didapatkan akan disusun untuk membuat pohon keputusan (decision tree), dan selanjutnya aplikasi berbasis Android mengadopsi hasil tersebut.

\section{Analisis Masalah}

Kebutuhan dan penggunaan laptop yang banyak sering diikuti oleh banyaknya permasalahan yang sering terjadi pada laptop yang digunakan. Bila permasalahan tersebut timbul, biasanya pengguna laptop yang masih awam tidak mengerti apa yang harus mereka lakukan. Biaya perbaikan laptop yang harus dibayar termasuk mahal. Tidak hanya itu, jika permasalahan tersebut dibawa ke tempat service laptop, ada beberapa teknisi laptop yang salah mendiagnosis kerusakannya karena kurang pemahaman atau pengalaman mengenai masalahnya.

\section{E. Penyelesaian Masalah}

Sistem pakar berbasis Android dapat mendiagnosis kerusakan hardware laptop secara tepat dan dapat diakses dengan mudah melalui smartphone secara langsung. Aplikasi sistem pakar ini dapat membantu para pengguna laptop lebih cepat mengetahui permasalahan atau gejala yang dialami, kerusakan apa yang terjadi pada laptop, dan solusi penanganan yang harus dilakukan dengan efisien. Pengguna laptop juga akan terhindar dari oknum tempat service yang tidak bertanggung jawab. Tidak hanya itu, teknisi laptop yang kurang pengalaman akan terbantu dalam mendiagnosis kerusakan laptop yang diperbaikinya supaya tidak terjadi kesalahan diagnosis.

\section{F. Desain Sistem}

Setelah mendapatkan semua ilmu pengetahuan yang ada melalui observasi dan wawancara dengan pakar, tahap berikutnya adalah membuat Pohon Keputusan atau Decision Tree dengan menggunakan metode Runut Maju atau yang istilahnya Forward Chaining. Metode tersebut bekerja dengan cara dimana pencocokan pernyataan atau faktanya dimulai dari fakta atau $I F$ terlebih dahulu, lalu dilanjutkan dengan THEN yang berisi hipotesisnya. Lalu, Pohon Keputusan menerjemahkannya dengan cara memetakan semua fakta pengetahuan yang didapatkan menjadi sebuah alternatif-alternatif sampai pada menemukan kesimpulan dari permasalahan yang diberikan dalam software McGoo. Selanjutnya, dibentuklah sistem aplikasi berbasis Android dengan mengadopsi hasilnya tersebut.

\section{G. Alur Kerja Sistem Pakar Aplikasi}

Cara kerja dari aplikasi sistem pakar yang dibuat dapat dilihat pada Gambar 1.

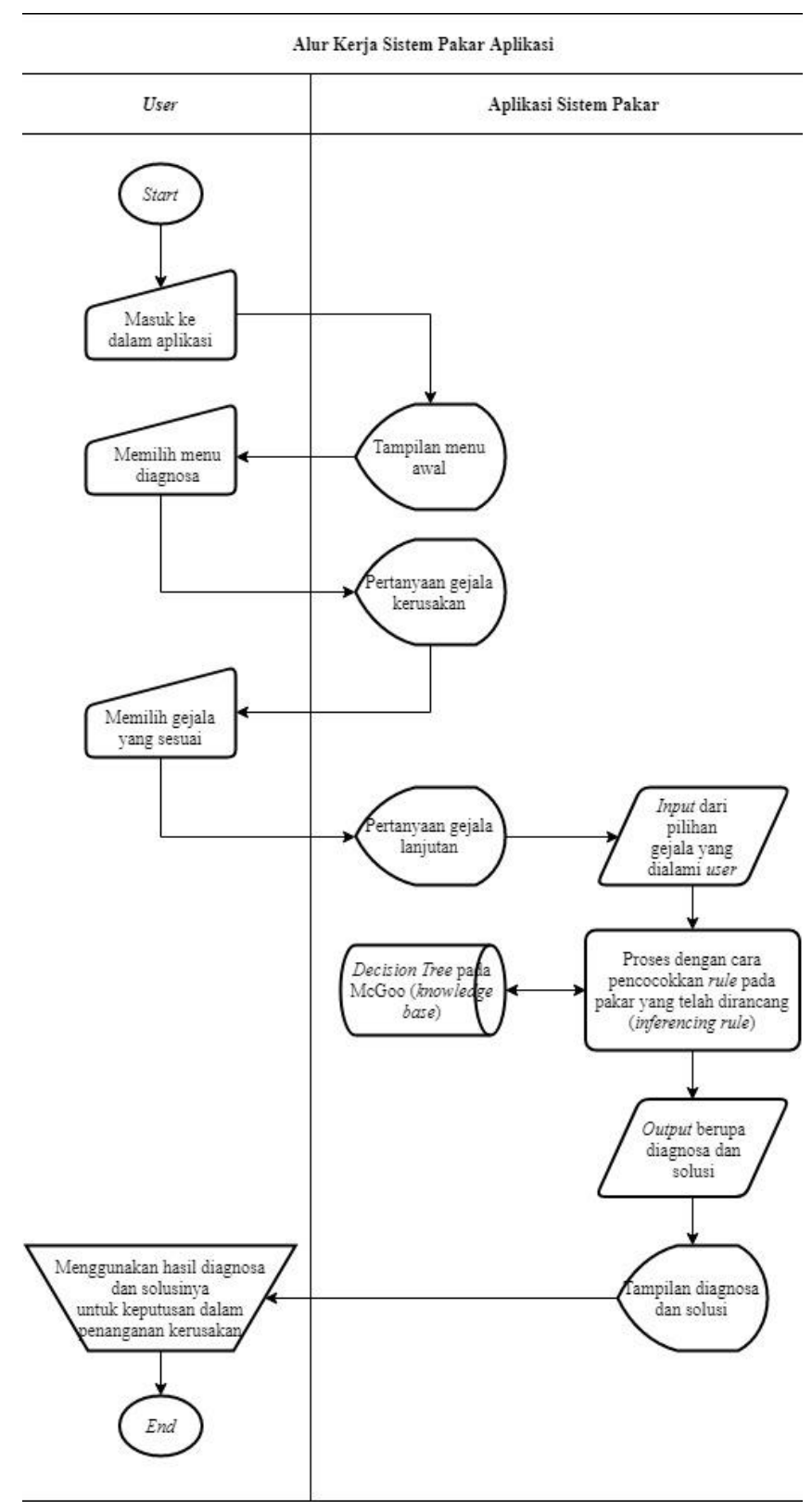

Gambar 1. Alur Kerja Sistem Pakar Aplikasi.

\section{H. Use Case Diagram Aplikasi}

Use Case merupakan sebuah pemodelan yang menjelaskan siapa saja yang berhak menggunakan fungsifungsi di dalam sistem dan apa saja yang dapat diperbuat. Dapat dilihat pada Gambar 2. 


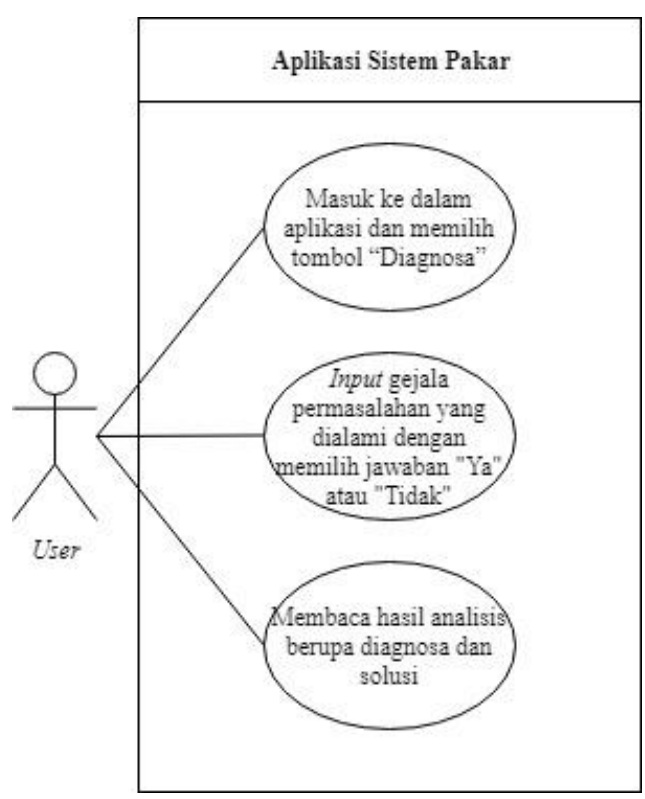

Gambar 2. Use Case Diagram.

I. Activity Diagram Aplikasi

Activity Diagram akan menjabarkan mengenai aktivitas yang dilakukan oleh user aplikasi dan sistem dari aplikasi itu sendiri. Aktivitas tersebut dimulai dari user membuka aplikasi sistem pakar pada smartphone. Di "Halaman Menu Utama", user memilih menu "Diagnosis" untuk memulai diagnosis laptop dan nantinya sistem akan menampilkan halaman pertanyaan secara beruntun. User menjawab pertanyaan dengan memilih "Ya" atau "Tidak" sesuai keadaan yang sebenarnya dan nantinya sistem akan menampilkan hasil diagnosis berupa konklusi dan solusi.

\section{J. Sequence Diagram Aplikasi}

Sequence Diagram akan menjabarkan mengenai interaksi antar objek dengan user yang disebut dengan aktor. User masuk ke dalam aplikasi dan selanjutnya sistem menampilkan "Halaman Menu Utama". Ketika user memilih menu "Diagnosis", sistem akan menampilkan "Halaman Menu Pertanyaan Diagnosis" dan berisi pertanyaan secara beruntun. Tiap pertanyaan memiliki dua pilihan jawaban "Ya" dan "Tidak" yang harus dipilih salah satunya oleh user dan sistem akan menampilkan "Halaman Hasil Diagnosis" berisi konklusi dan solusi.

\section{IMPLEMENTASI}

\section{A. Pembentukan Decision Tree}

Semua ilmu pengetahuan yang didapat hasil dari observasi dan wawancara dengan pakar tersebut dikumpulkan untuk membuat pohon keputusan (decision tree). Pohon Keputusan ini nantinya diterapkan dalam software McGoo. Dapat dilihat pada Gambar 3.

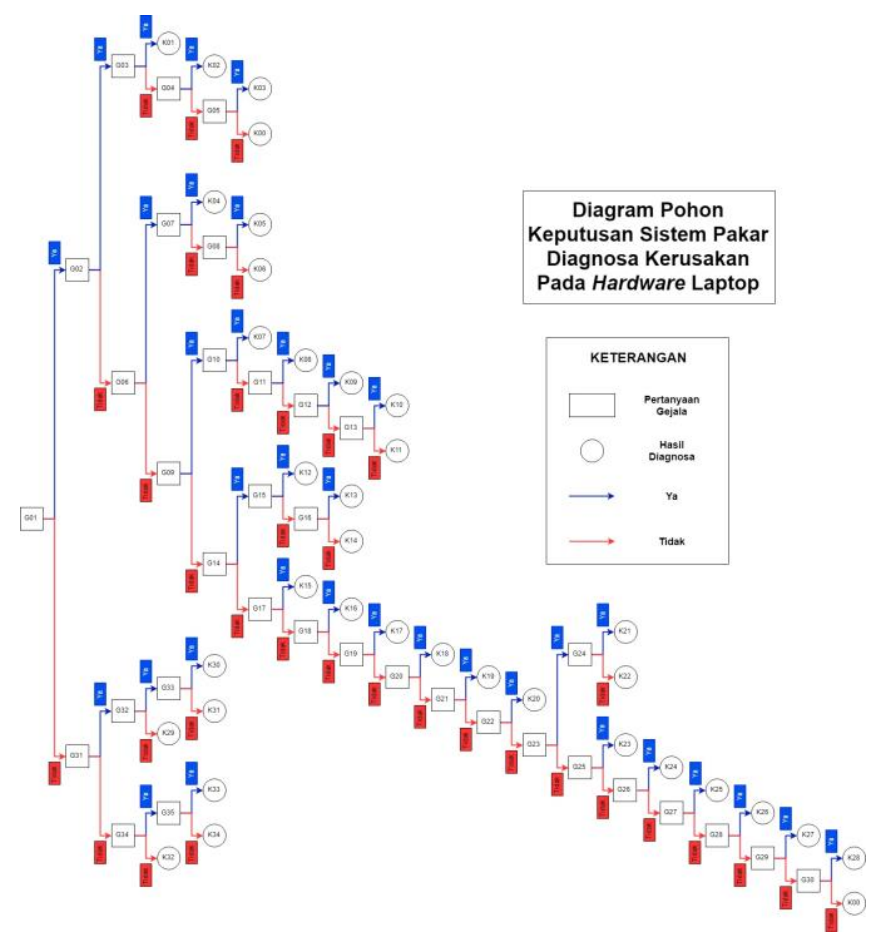

Gambar 3. Pohon Keputusan Sistem Pakar.

Dari diagram pohon keputusan di atas dapat dilihat alur pertanyaan dan hasil analisisnya. Pertanyaan yang tersedia hanya memiliki dua pilihan jawaban "Ya" dan "Tidak" untuk mendapatkan analisis. Untuk pilihan jawaban "Ya" berupa garis panah berwarna biru dan untuk pilihan jawaban "Tidak" berupa garis panah berwarna merah. Semua pertanyaan berbentuk persegi dan berkode "G". Keterangan dari tiap kode pertanyaan dapat dilihat pada Tabel 1.

Tabel 1. Keterangan Kode Pertanyaan.

\begin{tabular}{|c|c|}
\hline $\begin{array}{c}\text { Kode } \\
\text { Pertanyaan }\end{array}$ & Keterangan \\
\hline G01 & Apakah laptop dapat dihidupkan? \\
\hline G02 & $\begin{array}{l}\text { Apakah laptop tiba-tiba mati saat } \\
\text { mengoperasikan software atau program? }\end{array}$ \\
\hline G03 & $\begin{array}{l}\text { Lakukan pemeriksaan voltase pada adaptor } \\
\text { charger dengan multimeter, apakah } \\
\text { display menunjukkan hasil yang berubah } \\
\text { naik turun? }\end{array}$ \\
\hline G04 & $\begin{array}{l}\text { Apakah fan atau kipas processor tidak } \\
\text { terdengar suara putaran atau mati? }\end{array}$ \\
\hline G05 & $\begin{array}{l}\text { Apakah baterai drop atau cepat habis } \\
\text { dalam pemakaian laptop secara normal? }\end{array}$ \\
\hline G06 & Apakah layar LCD muncul bluescreen? \\
\hline G07 & $\begin{array}{l}\text { Apakah laptop sudah lama dipakai sekitar } \\
\text { lebih dari } 3 \text { tahun? }\end{array}$ \\
\hline G08 & $\begin{array}{l}\text { Apakah pernah menambah RAM baru } \\
\text { untuk menambah kecepatan RAM? }\end{array}$ \\
\hline G09 & Apakah laptop mengalami hang? \\
\hline
\end{tabular}




\begin{tabular}{|c|c|}
\hline $\begin{array}{c}\text { Kode } \\
\text { Pertanyaan }\end{array}$ & Keterangan \\
\hline G10 & $\begin{array}{l}\text { Apakah kondisi body laptop panas } \\
\text { berlebih atau overheating? }\end{array}$ \\
\hline G11 & $\begin{array}{l}\text { Apakah sering mengoperasikan laptop } \\
\text { untuk aplikasi game dan atau grafis yang } \\
\text { berat? }\end{array}$ \\
\hline G12 & $\begin{array}{l}\text { Apakah laptop sudah lama dipakai sekitar } \\
\text { lebih dari } 3 \text { tahun? }\end{array}$ \\
\hline G13 & $\begin{array}{l}\text { Apakah pernah menambah RAM yang } \\
\text { baru untuk menambah kecepatan RAM? }\end{array}$ \\
\hline G14 & Apakah laptop tiba-tiba restart sendiri? \\
\hline G15 & $\begin{array}{l}\text { Lakukan pemeriksaan voltase pada adaptor } \\
\text { charger dengan multimeter, apakah } \\
\text { display menunjukkan hasil yang berubah } \\
\text { naik turun? }\end{array}$ \\
\hline G16 & $\begin{array}{l}\text { Lakukan pemeriksaan RAM dan fisik } \\
\text { RAM (IC, PIN, dan jalur PCB), apakah } \\
\text { ada yang kotor atau rusak? }\end{array}$ \\
\hline G17 & $\begin{array}{l}\text { Apakah ada bunyi "beep" yang panjang } \\
\text { dan atau bisa berhenti ketika menekan } \\
\text { salah satu tombol keyboard? }\end{array}$ \\
\hline G18 & $\begin{array}{l}\text { Apakah touchpad-mouse tidak dapat } \\
\text { menggerakkan kursor secara normal? }\end{array}$ \\
\hline G19 & Apakah sound atau speaker tidak bunyi? \\
\hline G20 & $\begin{array}{l}\text { Apakah baterai drop atau cepat habis } \\
\text { dalam pemakaian laptop secara normal? }\end{array}$ \\
\hline G21 & $\begin{array}{l}\text { Apakah ada tampilan garis-garis horizontal } \\
\text { dan atau vertikal pada layar LCD? }\end{array}$ \\
\hline $\mathrm{G} 22$ & $\begin{array}{l}\text { Apakah kadang tampil gambar dan kadang } \\
\text { tidak ketika merubah posisi LCD ke depan } \\
\text { dan ke belakang? }\end{array}$ \\
\hline G23 & $\begin{array}{l}\text { Apakah tidak ada tampilan pada layar } \\
\text { LCD meskipun mesin laptop hidup? }\end{array}$ \\
\hline $\mathrm{G} 24$ & $\begin{array}{l}\text { Apakah ada tampilan gambar, jika laptop } \\
\text { dihubungkan ke LCD Monitor atau } \\
\text { Proyektor melalui output VGA Eksternal? }\end{array}$ \\
\hline $\mathrm{G} 25$ & Apakah LCD dalam kondisi pecah? \\
\hline G26 & $\begin{array}{l}\text { Apakah kamera tidak dapat menampilkan } \\
\text { gambar atau merekam video? }\end{array}$ \\
\hline G27 & $\begin{array}{l}\text { Apakah laptop tidak dapat terkoneksi atau } \\
\text { menjangkau semua jaringan internet, } \\
\text { meskipun posisi laptop tidak jauh dari } \\
\text { sumbernya? }\end{array}$ \\
\hline G28 & $\begin{array}{l}\text { Apakah pembacaan data CD atau DVD } \\
\text { tersendat-sendat atau tidak dapat terbaca? }\end{array}$ \\
\hline G29 & $\begin{array}{l}\text { Apakah pembacaan data dari USB yang } \\
\text { terhubung terputus-putus atau tidak dapat } \\
\text { terbaca? }\end{array}$ \\
\hline G30 & $\begin{array}{l}\text { Apakah tanggal dan waktu berubah saat } \\
\text { laptop dimatikan? }\end{array}$ \\
\hline G31 & $\begin{array}{l}\text { Apakah adaptor charger memiliki } \\
\text { indikator lampu? }\end{array}$ \\
\hline G32 & $\begin{array}{l}\text { Apakah indikator lampu pada adaptor } \\
\text { charger menyala? }\end{array}$ \\
\hline
\end{tabular}

\begin{tabular}{cl}
\hline $\begin{array}{c}\text { Kode } \\
\text { Pertanyaan }\end{array}$ & \multicolumn{1}{c}{ Keterangan } \\
\hline G33 & $\begin{array}{l}\text { Apakah jarum konektor pada port } \\
\text { konektor power putus atau patah? }\end{array}$ \\
G34 & $\begin{array}{l}\text { Lakukan pemeriksaan voltase pada adaptor } \\
\text { charger dengan multimeter, apakah } \\
\text { display menunjukkan angka sekitar 19 } \\
\text { volt? }\end{array}$ \\
\hline G35 & $\begin{array}{l}\text { Apakah jarum konektor pada port } \\
\text { konektor power putus atau patah? }\end{array}$ \\
\hline
\end{tabular}

Semua hasil analisis berbentuk lingkaran dan berkode "K". Keterangan dari tiap kode hasil analisis dapat dilihat pada Tabel 2.

Tabel 2. Keterangan Kode Hasil Analisis.

\begin{tabular}{|c|c|}
\hline $\begin{array}{l}\text { Kode Hasil } \\
\text { Analisis }\end{array}$ & Keterangan \\
\hline K01 & $\begin{array}{l}\text { Kerusakan pada adaptor charger laptop } \\
\text { yang tegangan listrik output-nya tidak } \\
\text { stabil. }\end{array}$ \\
\hline K02 & $\begin{array}{l}\text { Kipas processor yang tidak berputar akibat } \\
\text { banyaknya kotoran dan debu yang } \\
\text { menghambat. }\end{array}$ \\
\hline K03 & $\begin{array}{l}\text { Baterai rusak atau drop, beberapa sel } \\
\text { tertentu dalam baterai sudah tidak } \\
\text { berfungsi secara optimal. }\end{array}$ \\
\hline K04 & $\begin{array}{l}\text { RAM yang sudah lemah karena pemakaian } \\
\text { laptop yang telah berumur. }\end{array}$ \\
\hline K05 & $\begin{array}{l}\text { Kesalahan pembacaan data pada RAM } \\
\text { yang baru dengan motherboard karena } \\
\text { ketidaksesuaian spesifikasi RAM yang } \\
\text { dibutuhkan. }\end{array}$ \\
\hline K06 & $\begin{array}{l}\text { Kerusakan pada harddisk yang mengalami } \\
\text { bad sector lunak. }\end{array}$ \\
\hline K07 & $\begin{array}{l}\text { Lubang ventilasi pembuangan dari kipas } \\
\text { processor tertutup sehingga udara panas } \\
\text { tidak bisa keluar yang mengakibatkan } \\
\text { peningkatan panas berlebih di mesin } \\
\text { laptop. }\end{array}$ \\
\hline K08 & $\begin{array}{l}\text { Kondisi chipset motherboard, chipset } \\
\text { VGA, ataupun processor yang terlalu } \\
\text { panas. }\end{array}$ \\
\hline K09 & $\begin{array}{l}\text { RAM yang sudah lemah karena pemakaian } \\
\text { laptop yang telah berumur. }\end{array}$ \\
\hline K10 & $\begin{array}{l}\text { Kesalahan pembacaan data pada RAM } \\
\text { yang baru dengan motherboard karena } \\
\text { ketidaksesuaian spesifikasi RAM yang } \\
\text { dibutuhkan. }\end{array}$ \\
\hline K11 & $\begin{array}{l}\text { Kerusakan pada harddisk yang mengalami } \\
\text { bad sector lunak. }\end{array}$ \\
\hline K12 & $\begin{array}{l}\text { Kerusakan pada adaptor charger laptop } \\
\text { yang tegangan listrik output-nya tidak } \\
\text { stabil. }\end{array}$ \\
\hline K13 & $\begin{array}{l}\text { Bagian fisik RAM seperti bagian IC, PIN, } \\
\text { atau jalur PCB yang kotor atau mengalami } \\
\text { kerusakan. }\end{array}$ \\
\hline
\end{tabular}




\begin{tabular}{|c|c|}
\hline $\begin{array}{c}\text { Kode Hasil } \\
\text { Analisis }\end{array}$ & Keterangan \\
\hline K14 & $\begin{array}{l}\text { Kerusakan pada harddisk yang mengalami } \\
\text { bad sector lunak dan atau fisik. }\end{array}$ \\
\hline K15 & $\begin{array}{l}\text { Keyboard mengalami gangguan akibat } \\
\text { kotoran dan berdebu. }\end{array}$ \\
\hline K16 & Touchpad-mouse mengalami kerusakan. \\
\hline K17 & $\begin{array}{l}\text { Speaker internal atau IC sound laptop } \\
\text { dalam kondisi rusak atau mati. }\end{array}$ \\
\hline K18 & $\begin{array}{l}\text { Baterai rusak atau nge-drop, akibat dari } \\
\text { seringnya tersambung adaptor charger } \\
\text { sehingga pengisian baterai menjadi } \\
\text { berlebihan meskipun baterai sudah penuh } \\
\text { dan atau sambil mengoperasikan laptop. }\end{array}$ \\
\hline K19 & $\begin{array}{l}\text { Kerusakan pada bagian komponen } \\
\text { inverter. }\end{array}$ \\
\hline K20 & $\begin{array}{l}\text { Gangguan pada kendornya konektor VGA, } \\
\text { konektor kabel inverter, dan atau kabel } \\
\text { layar LCD. }\end{array}$ \\
\hline K21 & $\begin{array}{l}\text { Gangguan pada kendornya konektor VGA, } \\
\text { konektor kabel inverter, dan atau kabel } \\
\text { layar LCD. }\end{array}$ \\
\hline $\mathrm{K} 22$ & Kerusakan pada chipset VGA. \\
\hline K23 & $\begin{array}{l}\text { Kerusakan pada LCD yang pecah } \\
\text { diakibatkan dari benturan dengan benda } \\
\text { keras, jatuh, ataupun terkena tekanan yang } \\
\text { kuat. }\end{array}$ \\
\hline $\mathrm{K} 24$ & Kerusakan pada kamera laptop. \\
\hline $\mathrm{K} 25$ & $\begin{array}{l}\text { Kerusakan pada wireless atau biasanya } \\
\text { disebut wifi. }\end{array}$ \\
\hline K26 & $\begin{array}{l}\text { Kerusakan pada sensor optic yang terdapat } \\
\text { pada optical drive. }\end{array}$ \\
\hline K27 & Kerusakan pada port USB. \\
\hline $\mathrm{K} 28$ & Kerusakan pada CMOS baterai yang mati. \\
\hline K29 & $\begin{array}{l}\text { Kerusakan pada adaptor charger laptop } \\
\text { yang mati. }\end{array}$ \\
\hline K30 & $\begin{array}{l}\text { Kerusakan pada jarum konektor yang } \\
\text { terletak di dalam port konektor power } \\
\text { laptop dimana kemungkinan jarum } \\
\text { tersebut mengalami putus atau patah. }\end{array}$ \\
\hline K31 & $\begin{array}{l}\text { Kerusakan pada power supply atau IC } \\
\text { Power. }\end{array}$ \\
\hline K32 & $\begin{array}{l}\text { Kerusakan pada adaptor charger laptop } \\
\text { yang mati. }\end{array}$ \\
\hline K33 & $\begin{array}{l}\text { Kerusakan pada jarum konektor yang } \\
\text { terletak di dalam port konektor power } \\
\text { laptop dimana kemungkinan jarum } \\
\text { tersebut mengalami putus atau patah. }\end{array}$ \\
\hline K34 & $\begin{array}{l}\text { Kerusakan pada power supply atau IC } \\
\text { Power. }\end{array}$ \\
\hline K00 & $\begin{array}{l}\text { Membawa ke tempat service laptop atau } \\
\text { teknisi laptop untuk diagnosis lebih lanjut. }\end{array}$ \\
\hline
\end{tabular}

B. Implementasi Decision Tree ke Dalam McGoo

Tahap ini menjelaskan bagaimana pohon keputusan (decision tree) yang telah dibentuk sebelumnya diterapkan dalam software McGoo. Aplikasi ini digunakan untuk membuat sistem pakar berbasis web secara online yang sangat sederhana dan mudah dimengerti. Metode yang digunakan adalah forward chaining dimana pencocokan pernyataan atau faktanya dimulai dari gejala permasalahan atau $I F$ terlebih dahulu, lalu dilanjutkan dengan THEN yang berisi analisisnya.

1. Code

Dalam McGoo ini berisikan rule atau aturan berupa pertanyaan yang tiap pertanyaannya memiliki dua value, yaitu "Ya" dan "Tidak", serta terdapat konklusi berupa hasil analisis permasalahan yang terjadi. Contoh sebagian code dalam McGoo dapat dilihat pada Gambar 4.

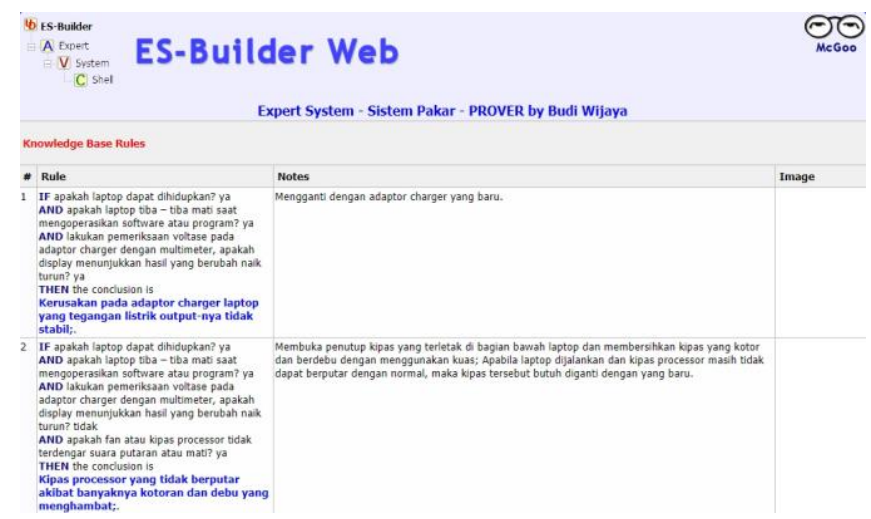

Gambar 4. Rule dan Conclusion.

\section{Tampilan McGoo}

Tampilan ini berupa user interface berisikan pertanyaan yang harus dijawab oleh pengguna untuk mendapatkan hasil analisis yang diinginkan. Terdapat dua pilihan jawaban "Ya" dan "Tidak" yang dapat dipilih sesuai kondisi permasalahan yang dihadapi. Tampilan awal dari McGoo dapat dilihat pada gambar 5 yang berisikan pertanyaan awal keadaan laptop yang sebenarnya. Pengguna dapat memilih antara "Ya" dan "Tidak" untuk melanjutkan pertanyaan lainnya.

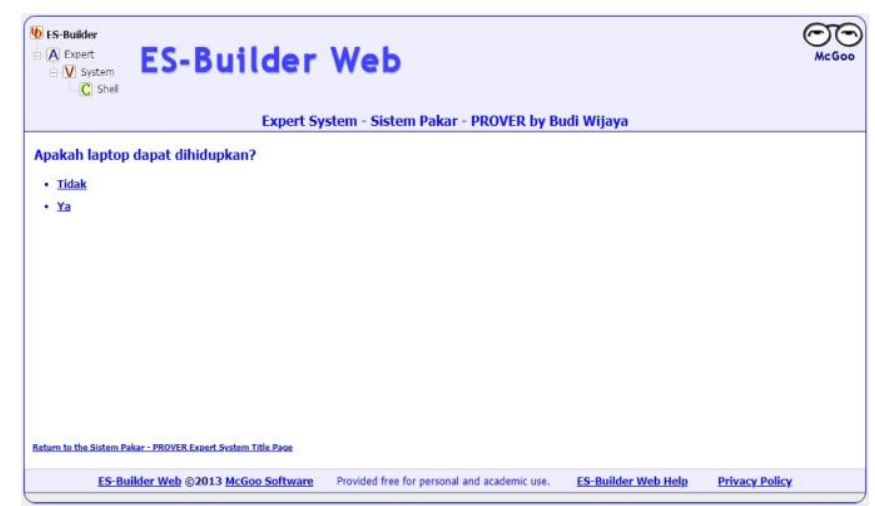

Gambar 5. Tampilan Awal McGoo. 
Tampilan pertanyaan lanjutan untuk memastikan permasalahan apa yang sebenarnya terjadi pada laptop pengguna supaya mendapatkan analisis yang tepat untuk mengatasinya. Dapat dilihat pada Gambar 6.

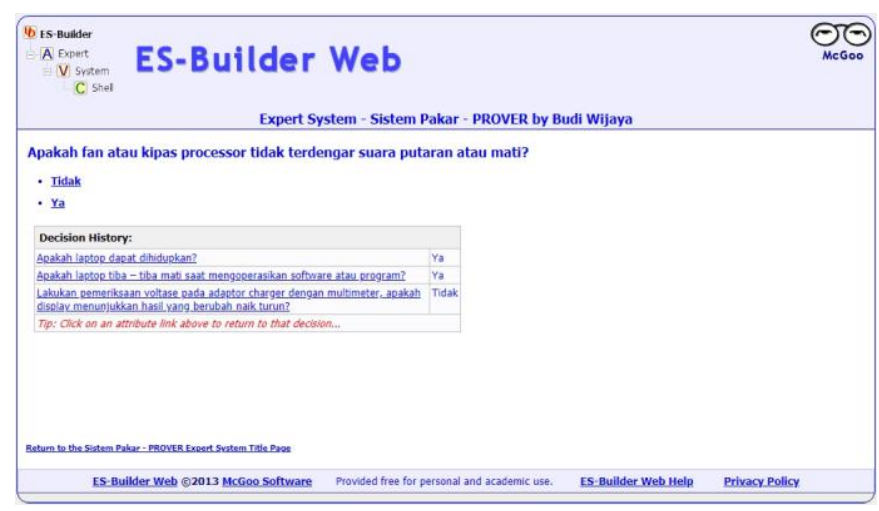

Gambar 6. Tampilan Pertanyaan Lanjutan.

Tampilan hasil analisis berupa konklusi permasalahan kerusakan apa yang sebenarnya terjadi dan beberapa tips cara mengatasinya. Dapat dilihat pada Gambar 7.

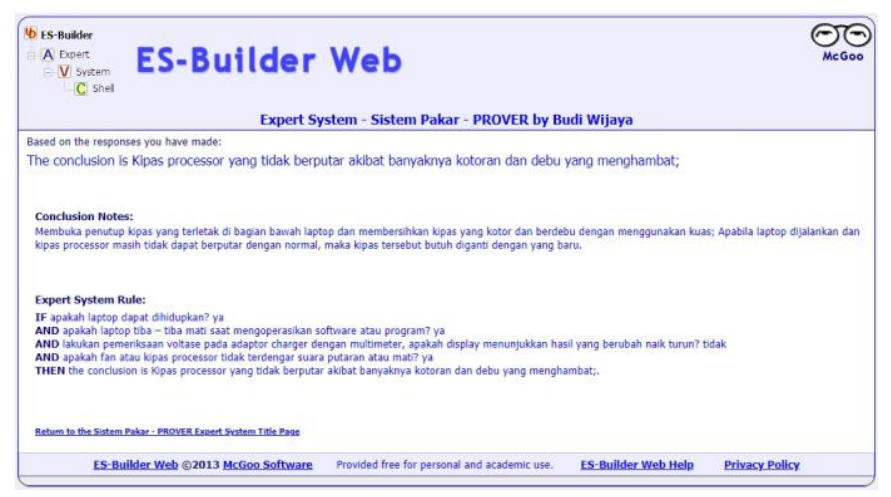

Gambar 7. Tampilan Hasil Analisis.

C. Implementasi Decision Tree ke Dalam Aplikasi

Tahap ini menjelaskan bagaimana pohon keputusan (decision tree) yang telah dibentuk sebelumnya diterapkan dalam Thunkable. Thunkable digunakan untuk membuat aplikasi berbasis web secara online yang memiliki desain sangat sederhana dan mudah dimengerti. Di dalam Thunkable terdapat dua bagian utama, yaitu "Design" untuk mengatur desain tampilan dari aplikasi yang diinginkan dan "Block" untuk mengatur semua perintah dalam aplikasi yang dibentuk.

Aplikasi yang terbentuk dapat diakses melalui smartphone berbasis Android. Nama dari aplikasi ini adalah "PROVER" dimana merupakan singkatan dari "Your Laptop Problem Resolver". Kegunaan dari aplikasi adalah untuk mendiagnosis kerusakan pada hardware laptop secara cepat dan tepat.

Dalam aplikasi yang dirancang ini memiliki beberapa bagian halaman utama beserta code-nya, sebagai berikut.

1. Code Halaman Depan

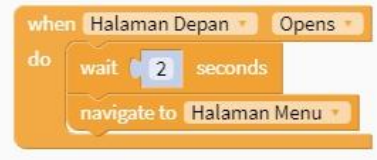

Gambar 8. Code Halaman Depan.

2. Code Halaman Menu Utama

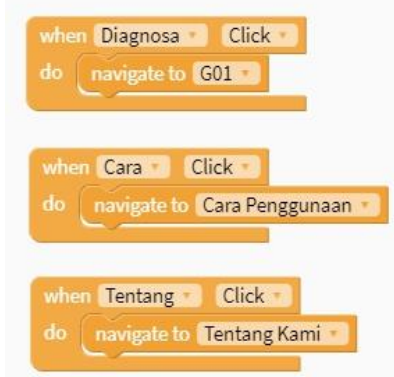

Gambar 9. Code Halaman Menu Utama.

3. Code Halaman Cara Penggunaan

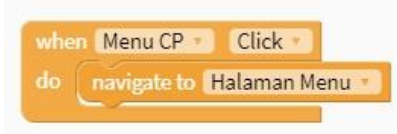

Gambar 10. Code Halaman Cara Penggunaan.

4. Code Halaman Tentang Kami

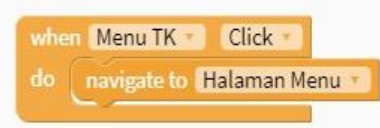

Gambar 11. Code Halaman Tentang Kami.

5. Code Halaman Menu Pertanyaan Diagnosis

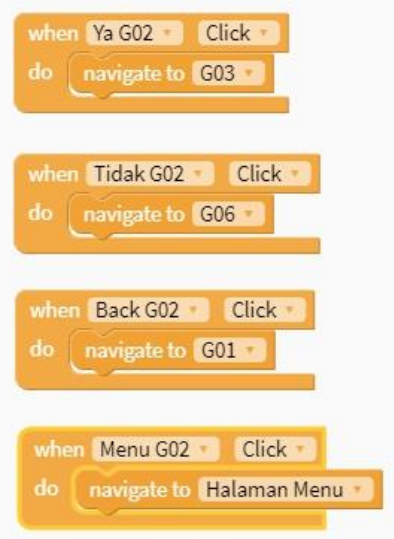

Gambar 12. Sebagian Code Halaman Menu Pertanyaan Diagnosis. 
6. Code Halaman Hasil Diagnosis

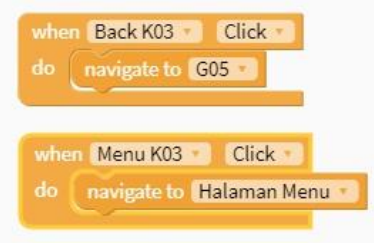

Gambar 13. Sebagian Code Halaman Hasil Diagnosis.

D. User Interface Aplikasi

1. Halaman Depan

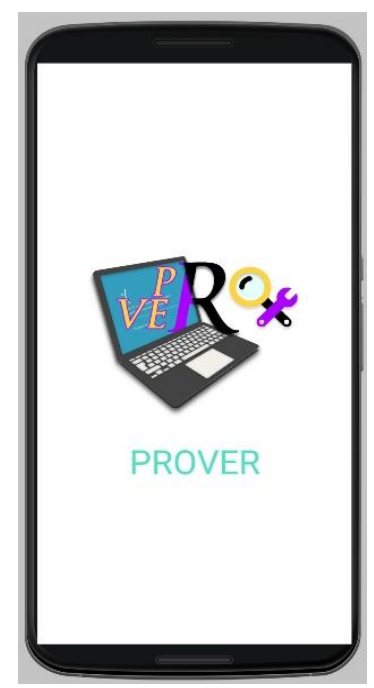

Gambar 14. User Interface Halaman Depan.

2. Halaman Menu Utama

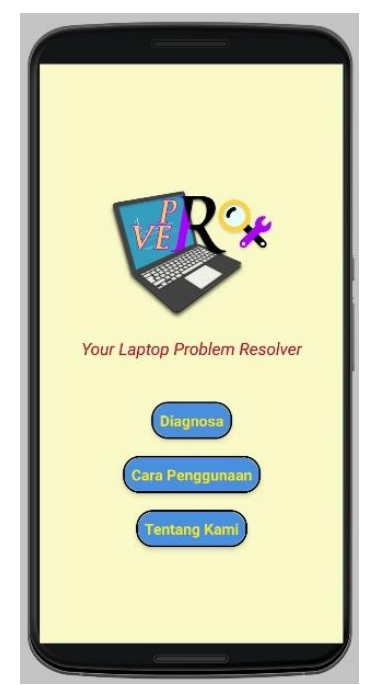

Gambar 15. User Interface Halaman Menu Utama.

3. Halaman Cara Penggunaan

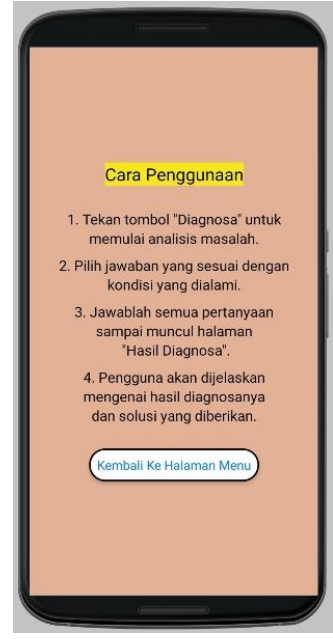

Gambar 16. User Interface Halaman Cara Penggunaan.

4. Halaman Tentang Kami

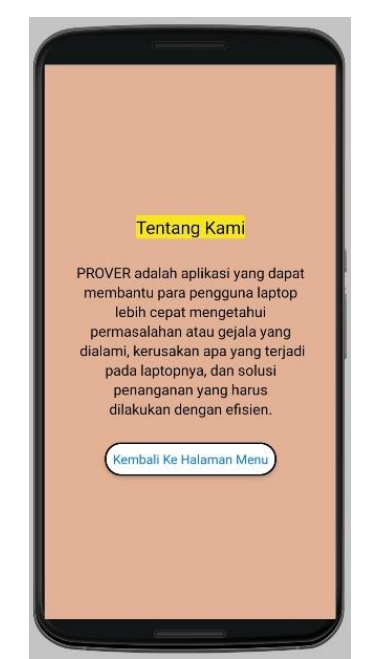

Gambar 17. User Interface Halaman Tentang Kami.

5. Halaman Menu Pertanyaan Diagnosis

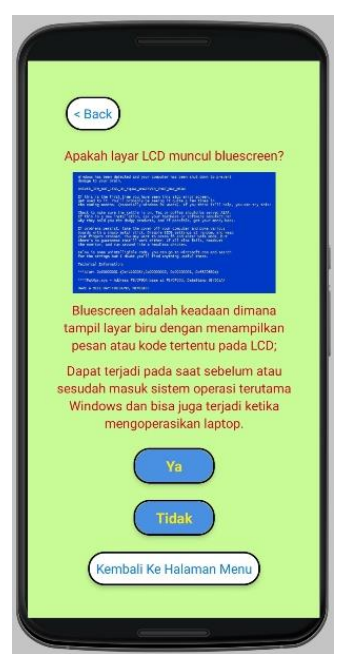

Gambar 18. User Interface Halaman Menu Pertanyaan Diagnosis. 
6. Halaman Hasil Diagnosis

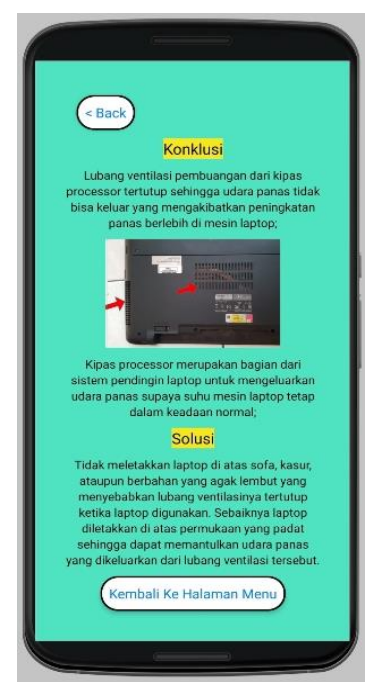

Gambar 19. User Interface Halaman Hasil Diagnosis.

\section{HASIL PENGUJIAN}

A. Pengujian Akurasi

Dalam tahap ini, peneliti akan melakukan pengujian akurasi dari aplikasi yang telah dibuat. Pengujian dilakukan dengan cara membandingkan hasil analisis dari aplikasi dengan hasil analisis dari teknisi laptop yang disebut pakar. Tujuannya supaya mendapatkan tingkat akurasi ketepatan secara maksimal. Dapat dilihat pada Tabel 3.

\section{B. Uji Coba Aplikasi Sistem Pakar Kepada User Laptop}

Tahap ini menjelaskan bagaimana aplikasi sistem pakar yang telah dibuat akan diuji coba kepada pengguna laptop. Pengujian ini menggunakan responden sebanyak 20 pengguna laptop. Pengguna nantinya akan menggunakan aplikasi untuk menganalisis permasalahan pada laptop dengan menjawab pertanyaan yang disediakan dalam aplikasi secara runtut. Dengan menjawab semua pertanyaan yang ada, maka aplikasi memberikan hasil analisisnya dan solusi permasalahan. Kemudian peneliti akan memberikan kuesioner offline untuk diisi oleh pengguna laptop tersebut. Tujuan dari pengisian kuesioner itu adalah mendapatkan penilaian bagaimana tingkat kepuasan pengguna memakai aplikasi, serta kritik dan saran yang membangun untuk pengembangan aplikasi PROVER.

Tabel 3. Pengujian Aplikasi.

\begin{tabular}{|c|c|c|c|c|}
\hline No. & Gejala yang Dialami & Hasil Analisis Aplikasi & Hasil Analisis Pakar & $\begin{array}{c}\text { Sesuai atau } \\
\text { Tidak } \\
\text { Sesuai } \\
\end{array}$ \\
\hline 1. & $\begin{array}{l}\text { Laptop tiba-tiba mati sendiri; } \\
\text { Kipas processor tidak terdengar } \\
\text { suara putaran. }\end{array}$ & $\begin{array}{l}\text { Kipas processor yang tidak berputar } \\
\text { akibat banyaknya kotoran dan debu } \\
\text { yang menghambat. }\end{array}$ & Kipas processor mati. & Sesuai \\
\hline 2. & $\begin{array}{l}\text { Laptop tiba-tiba mati sendiri; } \\
\text { Baterai cepat habis dalam } \\
\text { pemakaian laptop secara normal. }\end{array}$ & Baterai rusak atau ngedrop. & $\begin{array}{l}\text { Baterai rusak atau sudah } \\
\text { tidak berfungsi. }\end{array}$ & Sesuai \\
\hline 3. & $\begin{array}{l}\text { Layar tampil bluescreen; } \\
\text { Pemakaian laptop yang telah } \\
\text { berumur. }\end{array}$ & $\begin{array}{l}\text { RAM yang sudah lemah karena } \\
\text { pemakaian laptop yang telah } \\
\text { berumur. }\end{array}$ & $\begin{array}{l}\text { Kondisi RAM yang } \\
\text { lemah. }\end{array}$ & Sesuai \\
\hline 4. & Layar tampil bluescreen. & $\begin{array}{l}\text { Kerusakan pada harddisk yang } \\
\text { mengalami bad sector lunak. }\end{array}$ & $\begin{array}{l}\text { Hard disk mengalami bad } \\
\text { sector lunak. }\end{array}$ & Sesuai \\
\hline 5. & $\begin{array}{l}\text { Laptop kondisi hang; } \\
\text { Kondisi body laptop overheating. }\end{array}$ & $\begin{array}{l}\text { Lubang ventilasi pembuangan dari } \\
\text { kipas processor tertutup sehingga } \\
\text { udara panas tidak bisa keluar. }\end{array}$ & $\begin{array}{l}\text { Lubang ventilasi } \\
\text { pembuangan dari kipas } \\
\text { processor tertutup. }\end{array}$ & Sesuai \\
\hline 6. & $\begin{array}{l}\text { Laptop kondisi hang; } \\
\text { Sering mengoperasikan laptop } \\
\text { untuk aplikasi game dan atau grafis } \\
\text { yang besar dan berat. }\end{array}$ & $\begin{array}{l}\text { Kondisi chipset motherboard, } \\
\text { chipset VGA, ataupun processor } \\
\text { yang terlalu panas. }\end{array}$ & $\begin{array}{l}\text { Kondisi chipset } \\
\text { motherboard, chipset } \\
\text { VGA, ataupun processor } \\
\text { yang terlalu panas. }\end{array}$ & Sesuai \\
\hline 7. & $\begin{array}{l}\text { Laptop tiba-tiba restart sendiri; } \\
\text { Hasil pemeriksaan RAM yang } \\
\text { fisiknya ada kotoran atau rusak. }\end{array}$ & $\begin{array}{l}\text { Bagian fisik RAM seperti bagian IC, } \\
\text { PIN, atau jalur PCB yang kotor atau } \\
\text { mengalami kerusakan. }\end{array}$ & Bagian fisik RAM kotor. & Sesuai \\
\hline 8. & $\begin{array}{l}\text { Bunyi "beep" yang panjang; } \\
\text { Beberapa tombol keyboard tidak } \\
\text { berfungsi; } \\
\text { Ada tombol yang menekan sendiri. }\end{array}$ & $\begin{array}{l}\text { Keyboard mengalami gangguan } \\
\text { akibat kotoran dan berdebu. }\end{array}$ & $\begin{array}{l}\text { Kerusakan pada } \\
\text { keyboard. }\end{array}$ & Sesuai \\
\hline 9. & $\begin{array}{l}\text { Layar muncul garis - garis warna } \\
\text { putih. }\end{array}$ & $\begin{array}{l}\text { Kerusakan pada bagian komponen } \\
\text { inverter. }\end{array}$ & $\begin{array}{l}\text { Komponen inverter yang } \\
\text { rusak. }\end{array}$ & Sesuai \\
\hline
\end{tabular}




\begin{tabular}{llll}
\hline \multicolumn{1}{c}{ Gejala yang Dialami } & \multicolumn{1}{c}{ Hasil Analisis Aplikasi } & Hasil Analisis Pakar & $\begin{array}{c}\text { Sesuai atau } \\
\text { Tidak } \\
\text { Sesuai }\end{array}$ \\
\hline $\begin{array}{l}\text { Tidak ada tampilan apapun di layar } \\
\text { LCD; }\end{array}$ & Kerusakan pada chipset VGA. & Chipset VGA rusak. & Sesuai \\
$\begin{array}{l}\text { Projektor ataupun monitor tidak } \\
\text { dapat menampilkan gambar dari } \\
\text { layar LCD utama. }\end{array}$ & $\begin{array}{l}\text { Kerusakan pada adaptor } \text { charger } \\
\text { laptop yang mati. }\end{array}$ & $\begin{array}{l}\text { Adaptor } \text { charger tidak } \\
\text { berfungsi atau mati. }\end{array}$ & Sesuai \\
\hline $\begin{array}{l}\text { Indikator lampu adaptor tidak } \\
\text { nyala. }\end{array}$ & $\begin{array}{l}\text { Kaptop tidak dapat dihidupkan atau } \\
\text { mati total. }\end{array}$ & IC Power Power rusak. & Sesuai \\
\hline 12. & &
\end{tabular}

C. Hasil Kuesioner

Kuesioner yang dibuat berisikan tanggapan kepuasan mengenai aplikasi yang digunakan oleh user. Nantinya user memberikan penilaian di tiap pertanyaan dalam kuesioner. Tiap pertanyaan memiliki 5 tingkat skor penilaian jawaban berdasarkan pengukuran Skala Likert [6]. Dapat dilihat pada Tabel 4.

Tabel 4. Skala Likert

\begin{tabular}{clr}
\hline $\begin{array}{c}\text { Tingkat } \\
\text { Skor }\end{array}$ & \multicolumn{1}{c}{ Keterangan } & \multicolumn{1}{l}{ Nilai } \\
\hline 1 & Sangat Tidak Setuju & $0 \%-19,99 \%$ \\
\hline 2 & Tidak Setuju & $20 \%-39,99 \%$ \\
\hline 3 & Netral & $40 \%-59,99 \%$ \\
\hline 4 & Setuju & $60 \%-79,99 \%$ \\
\hline 5 & Sangat Setuju & $80 \%-100 \%$ \\
\hline
\end{tabular}

Setelah mengumpulkan semua penilaian dari 20 responden, peneliti menghitung total skor yang didapat dari tiap pertanyaan. Dapat dilihat pada Tabel 5.

Tabel 5. Hasil Persentase Skala Likert Kuesioner

\begin{tabular}{clc}
\hline No. & \multicolumn{1}{c}{ Pertanyaan } & Nilai \\
\hline 1. & $\begin{array}{l}\text { Aplikasi PROVER mudah } \\
\text { digunakan. }\end{array}$ & $85 \%$ \\
\hline 2. & $\begin{array}{l}\text { Aplikasi PROVER mudah } \\
\text { dimengerti dan dipahami. }\end{array}$ & $87 \%$ \\
\hline 3. & $\begin{array}{l}\text { Aplikasi PROVER memiliki } \\
\text { tampilan yang menarik. }\end{array}$ & $79 \%$ \\
\hline 4. & $\begin{array}{l}\text { Aplikasi PROVER berguna dan } \\
\text { membantu bagi saya. }\end{array}$ & $91 \%$ \\
\hline 5. & $\begin{array}{l}\text { Aplikasi PROVER memberikan } \\
\text { informasi yang benar dan tepat. }\end{array}$ & $86 \%$ \\
\hline
\end{tabular}

\section{HASIL PENGUJIAN}

A. Kesimpulan

Beberapa kesimpulan yang didapat dari penelitian aplikasi sistem pakar yang telah dibuat dan diuji, sebagai berikut.

Penyusunan fakta, aturan, dan ilmu pengetahuan berasal dari studi literatur, observasi, dan hasil wawancara terhadap teknisi yang menangani laptop sebagai pakar. Tujuannya untuk membentuk pohon keputusan menggunakan metode forward chaining yang kemudian diimplementasikan ke dalam McGoo Software sebagai Expert System Shell dan Thunkable sebagai pembuat aplikasi sistem pakar PROVER.

Aplikasi sistem pakar PROVER dapat diakses pada smartphone berbasis Android. Hasil pengujian tingkat akurasi ketepatan analisis dari aplikasi PROVER yang telah dibuat sudah sesuai $100 \%$ terhadap keadaan lapangan yang sebenarnya.

Hasil pengujian tingkat kepuasan pengguna memakai aplikasi PROVER berdasarkan pengukuran Skala Likert, sebagai berikut: Nilai tentang kemudahan untuk menggunakan aplikasi sebesar 85\%. Nilai tentang kemudahan aplikasi untuk dimengerti dan dipahami sebesar 87\%. Nilai tentang tampilan aplikasi sebesar 79\%. Nilai tentang aplikasi berguna dan membantu pengguna laptop sebesar $91 \%$. Nilai tentang aplikasi memberikan informasi yang benar dan tepat sebesar $86 \%$.

\section{B. Saran}

Beberapa saran yang didapat dari penelitian aplikasi sistem pakar yang telah dibuat dan diuji untuk pengembangan yang lebih baik lagi, sebagai berikut.

1. Menambahkan fitur untuk mengisi gejala sendiri oleh user di luar pertanyaan gejala yang telah tersedia.

2. Menambahkan fitur khusus berupa kumpulan istilah penting bagian hardware laptop.

3. Tampilan dibuat lebih menarik.

4. Video, gambar, dan tulisan lebih diperbesar lagi.

\section{UCAPAN TERIMA KASIH}

Penulis ingin menyampaikan rasa terima kasih sebesarbesarnya kepada:

1. Tuhan Yang Maha Esa atas rahmat, berkat, dan kasih karunia-Nya sehinga penulis diberikan kelancaran dan pencerahan setiap langkah dalam penulisan.

2. Dosen pembimbing yang senantiasa meluangkan waktu dan pemikirannya di sela-sela kesibukan beliau untuk menuntun, membimbing, mengarahkan, memberi motivasi, serta saran.

3. Orang tua dan saudara kandung dari penulis yang selalu memberi semangat, dukungan, doa, dan motivasi. 


\section{REFERENSI}

[1] Perkasa, A. \& Santhika, E. (2018). Pasar Laptop Terus Mendominasi, Gerus Desktop dan Komersial. Diakses dari CNN Indonesia: https://www.cnnindonesia.com/ teknologi/20180427093102-185294019/pasar-laptopterus-mendominasi-gerus-desktop-dan-komersial pada tanggal 28 April 2018.

[2] Hayadi, B.H. \& Rukun, K. (2016). What is Expert System. Yogyakarta: Deepublish Publisher.

[3] McGoo Software. (n.d.). About ES-Builder Web. Diakses dari McGoo: https://www.mcgoo.com.au/ html/es-builder_web.php
[4] Jubilee Enterprise. (2015). Mengenal Dasar-Dasar Pemrograman Android. Jakarta: PT Elex Media Komputindo.

[5] Nofriansyah, D. (2014). Konsep Data Mining Vs Sistem Pendukung Keputusan. Yogyakarta: Deepublish Publisher.

[6] Tanamal, R. (2017). Analisis Faktor yang Paling Berpengaruh Pada Keinginan Menggunakan Aplikasi Grab di Kota Surabaya. Jurnal Terapan Teknologi Informasi, Universitas Kristen Duta Wacana, Vol. 1, No. 2, pp. 119-128. 